\begin{tabular}{|l|l|l|l|l|l|l|}
\hline InterteXto & Uberaba & UFTM & $\begin{array}{l}\text { v. 2 } \\
\text { n. } 2\end{array}$ & p. 52-74 & 2009 - jul. / dez. & ISSN 1981-0601 \\
\hline
\end{tabular}

\title{
A CONSTRUÇÃO TOPOFÓBICA EM O POÇO E O PÊNDULO
}

\section{THE TOPOPHOBIC CONSTRUCTION IN THE PIT AND THE PENDULUM}

\author{
Ozíris Borges Filho ${ }^{1}$ \\ Nilfan Fernandes da Silva Júnior ${ }^{2}$ \\ Raysa Barbosa Correa Lima Pacheco ${ }^{3}$
}

Resumo: O objetivo da pesquisa é analisar o conto $O$ poço e o pêndulo de Edgar Allan Poe, publicado em 1842. Desse modo, observaremos todas as representações dos espaços fechados e suas axiologias dentro da narrativa. Para isso, utilizaremos a metodologia da Topoanálise.

Palavras-chave: Topoanálise; Tortura; Morte; Topofobia.

Abstract: The objective of this paper is to analyze the short story of The pit and the pendulum by Edgar Allan Poe, published in 1842. In this way, we analyze the closed space and its symbologies in the short story. For this, we use the method of Topoanalysis.

Key-words: Topoanalysis; Torture; Death; Topophobia.

\section{Introdução}

O conto $O$ poço e o pêndulo (The pit and the pendulum), do escritor norte-americano Edgar Allan Poe, concentra-se no terror psicológico advindo do interior de seu protagonista. O escritor, ao contrário dos demais autores que focalizavam o terror externo, unia as inquietações humanas aos aspectos ambientais da narrativa.

Escrito em 1842, narra a história de um homem que foi condenado e se encontra dentro de uma grande prisão, em um poço com um pêndulo. É um exemplo clássico do estilo gótico e de terror no qual Poe é mestre. O medo, a aflição causada pela presença da morte, o desespero e até mesmo a revolução vivida na época são os temas principais do conto.

\footnotetext{
${ }^{1}$ Professor na Universidade Federal do Triângulo Mineiro - UFTM. oziris@oziris.pro.br

${ }^{2}$ Graduando em Letras - UFTM. nilfanjr@hotmail.com

${ }^{3}$ Graduanda em Letras - UFTM. raysa pacheco@hotmail.com
} 


\begin{tabular}{|l|l|l|l|l|l|l|}
\hline InterteXto & Uberaba & UFTM & $\begin{array}{l}\text { v. 2 } \\
\text { n. } 2\end{array}$ & p. 52-74 & 2009 - jul. / dez. & ISSN 1981-0601 \\
\hline
\end{tabular}

Nossa intenção é analisar a construção espacial desse conto. Para tanto, iremos utilizar a proposta da Topoanálise.

\section{Espaços}

O conto se passa em apenas dois espaços, e o que chama atenção é a indeterminação deles por parte do narrador. O enredo narra a história de um homem que é julgado e condenado à morte em algum local e depois é preso num lugar que ele não sabe onde nem como é. O seu atordoamento, devido à falta de claridade e à sua fraqueza física, o deixa ainda mais confuso.

Os locais onde se encontra entram em sintonia com a situação vivida pelo personagem. Porém, é na prisão onde ele fica encarcerado, totalmente construída para causar impacto e uma impressão sombria, que toda a sua aflição se estabelece, até mesmo em todos os seus elementos simbólicos.

Por isso, o enredo narra a tentativa do protagonista de descobrir como é o lugar em que se encontra preso e, também, como escapar dele. Passemos agora à análise desses espaços.

\section{Espaço da sentença}

O conto tem início com o personagem protagonista exausto e esperando pela sua sentença; ele fora julgado e condenado à morte. É narrado em primeira pessoa, como podemos ver no seguinte trecho:

Eu via os lábios dos juízes vestidos de preto. Pareciam-me brancos, mais brancos do que a folha de papel sobre a qual traço estas palavras, delgados até o grotesco; delgados pela intensidade de sua expressão de firmeza, de imutável resolução, de severo desprezo pela dor humana. (POE, 2008, p. 109)

De acordo com a teoria de GENETTE (1977), o narrador do conto pode ser classificado como homo e autodiegético, pois ele participa da história e é o protagonista da mesma. O narrador, protagonista e herói do conto, também pode ser classificado como extradiegético, pois ele é o produtor do discurso 


\begin{tabular}{|l|l|l|l|l|l|l|}
\hline InterteXto & Uberaba & UFTM & $\begin{array}{l}\text { v. 2 } \\
\text { n. } 2\end{array}$ & p. 52-74 & 2009 - jul. / dez. & ISSN 1981-0601 \\
\hline
\end{tabular}

narrativo (a passagem que diz "a folha de papel sobre a qual traço estas palavras" comprova isso).

Esse trecho, além de explicitar de maneira clara a condição do narrador, nos adianta um fato em relação ao conto. Se é o protagonista quem agora relata sua própria história de terror e desespero é porque, de alguma forma, ele conseguiu escapar daquele espaço em que se encontrava preso. Assim, temos uma prolepse, ou seja, uma antecipação de que o personagem obterá algum êxito, conseguindo alcançar sua liberdade apesar da sentença de morte dos juízes. Fica bem definida então a diferença entre o espaço da narrativa e o espaço da narração. A narrativa se passa nessa espécie de "tribunal", em que o homem aguarda sua sentença e, como veremos mais a diante, no calabouço em que ele é preso. O espaço da narração é aquele onde o narrador, que também é personagem, conta sua história. O lugar da narração não pode ser definido por falta de elementos no conto que o caracterizam. Só se sabe de sua existência e que o espaço da narrativa não coincide com o da narração.

O protagonista, atordoado e confuso, começa a falar sobre as vagas impressões que começava a ter do espaço em que se encontrava.

Via também, durante alguns momentos de delirante terror, a ondulação leve e quase imperceptível dos panejamentos negros que revestiam as paredes da sala. E, depois, meu olhar caiu sobre as sete grandes velas em cima da mesa. A princípio, elas tomaram o aspecto da Caridade, e pareciam anjos brancos e esbeltos, que me salvariam; depois, de súbito, sobreveio-me ao espírito uma náusea das mais mortais, e senti cada uma das fibras de meu corpo vibrar, como se eu tivesse tocado o fio de uma pilha galvânica, enquanto os vultos angélicos se transformavam em espectros insignificantes, com cabeças de chama, e eu via bem que deles não teria socorro. (POE, 2008, p. 109-110)

No trecho acima, temos a exposição do espaço, introduzindo o local em que ele fora sentenciado. O verbo no pretérito imperfeito (via) mostra o caráter descritivo dessa passagem, em que a espacialização nos é apresentada pelo personagem e por isso pode ser chamada de reflexa. Algumas coordenadas 


\begin{tabular}{|l|l|l|l|l|l|l|}
\hline InterteXto & Uberaba & UFTM & $\begin{array}{l}\text { v. 2 } \\
\text { n. 2 }\end{array}$ & p. 52-74 & 2009 - jul. / dez. & ISSN 1981-0601 \\
\hline
\end{tabular}

espaciais podem ser depreendidas, como a da verticalidade, em que as velas se encontram numa posição mais alta; a luz, que remete à salvação, vem de cima, trazendo um pouco de luminosidade para o local. Também se percebe a questão da interioridade, pois o espaço é fechado, interior. Comprova-se isso porque era delimitado por paredes, e o fato de causar náuseas no personagem indica que era um local fechado e pouco ventilado.

A presença de alguns elementos evidencia como o espaço pode ser considerado topofóbico: desperta no personagem um "delirante terror", as paredes são revestidas de panos negros, há velas que sugerem uma baixa luminosidade. Dessa maneira, é explorado o gradiente sensorial da visão, que expressa a primeira impressão do homem quanto ao local. Todos esses aspectos citados causam náusea no protagonista, o que mostra o tanto que o espaço é desagradável e aterrorizante. Por isso a relação de topopatia, ou seja, a relação sentimental entre o personagem e o espaço, se constitui de uma topofobia (o espaço é maléfico e negativo). Pode-se inferir, também, a formação de um ambiente; ao espaço se agrega um clima psicológico, no caso do conto, um clima negativo. A quase ausência de luz, as velas e as sombras contribuem para a formação desse ambiente macabro, que sugere ações macabras: a condenação à morte. Aliás, o ambiente se avoluma durante o conto.

Outro ponto interessante a ser destacado no trecho é a presença da cor negra (panejamentos negros). A cor negra é, majoritariamente, associada a uma conotação negativa. De acordo com o Dicionário de símbolos (2008, p. 633), essa cor pode ser relacionada às trevas primordiais, às regiões infernais, ao caos, à angústia, ao inconsciente e é a cor da condenação. Para o conto, esses significados são totalmente coerentes; o personagem vive um verdadeiro inferno pessoal na sua espera pela morte, está angustiado, não tem muita noção do espaço em que se encontra e está condenado a um destino ao qual, inicialmente, não pode escapar. Por isso, a escuridão do lugar já sugere o teor macabro do desenrolar da narrativa. 


\begin{tabular}{|l|l|l|l|l|l|l|}
\hline InterteXto & Uberaba & UFTM & $\begin{array}{l}\text { v. 2 } \\
\text { n. } 2\end{array}$ & p. 52-74 & 2009 - jul. / dez. & ISSN 1981-0601 \\
\hline
\end{tabular}

Alguns elementos presentes nesse trecho mostram que, de acordo com a Topoanálise, se trata de um microespaço que pode ser classificado como um cenário. Isso porque foi construído pelo homem: panejamentos, paredes, sala, velas, mesa são todos elementos provenientes da cultura humana, não encontrados na natureza.

Então, insinuou-se em minha imaginação, como rica nota musical, a idéia do tranqüilo repouso de que haveria de desfrutar na sepultura. Tal idéia chegou doce e furtivamente, e parece ter surgido muito tempo antes que pudesse ser completamente apreciada. Mas, no momento mesmo em que meu espírito começava, enfim, a senti-la propriamente e a acarinhá-la, os vultos dos juízes desapareceram da minha frente como mágica; as altas tochas reduziram-se a nada; suas chamas se apagaram por completo; o negror da treva sobreveio. Todas as sensações pareceram ter sido engolidas num louco e precipitado mergulho, como se a alma se afundasse no Hades. E o universo não era mais do que noite, silêncio e imobilidade. (POE, 2008, p. 110)

No excerto acima, vê-se uma figura de linguagem, a comparação. O narrador compara a calma sonora de uma nota musical (explorando o gradiente sensorial da audição) à tranqüilidade que a morte poderia proporcionar a ele. Era melhor desfalecer logo do que permanecer na angustiante espera pela morte. Em seguida, vemos que a morte é personificada, quando o protagonista diz senti-la e acarinhá-la; ao usar esses verbos, ele atribui características humanas a ela, que estava tão iminente que era sua única companhia naquele misterioso espaço.

Mais uma vez, o gradiente sensorial da visão é explorado. O personagem perde os sentidos, e usa várias metáforas para indicar sua condição de inconsciência (os vultos desaparecem, as chamas se apagam, as tochas se reduzem a nada). Através do gradiente da visão (trevas) e da audição (silêncio), pode-se depreender, juntamente com a imobilidade, essa idéia do desmaio. Isso comprova a topofobia associada ao lugar, capaz de causar a perda de consciência no homem que ali estava contido. 


\begin{tabular}{|l|l|l|l|l|l|l|}
\hline InterteXto & Uberaba & UFTM & $\begin{array}{l}\text { v. 2 } \\
\text { n. } 2\end{array}$ & p. 52-74 & 2009 - jul. / dez. & ISSN 1981-0601 \\
\hline
\end{tabular}

Nas próximas passagens, o narrador descreve como se sentiu durante aquele período de perda de consciência, em que ele não achava estar totalmente desmaiado por ter tido algumas sensações atípicas. Isso comprova os delírios pelos quais ele passava, pois estava num lugar escuro, esperando pela morte e, como veremos mais adiante, mal alimentado e fisicamente debilitado. Na tentativa de se lembrar do que aconteceu, o personagem descreve:

Essas sombras de memória falam indistintamente de altas
figuras que se erguiam e me arrastavam em silêncio... para
baixo, cada vez mais baixo, até que uma odiosa vertigem me
oprimiu à simples idéia daquela descida interminável. Falam-
me, também, de um vago horror no coração, por causa daquele
mesmo sossego desnatural do coração. Depois, sobrevém uma
sensação de súbita imobilidade em todas as coisas, como se
aqueles que me transportavam (cortejo espectral!) houvessem,
em sua descida, ultrapassado os limites do ilimitado e se detido
em razão do extremo cansaço da tarefa. Em seguida, evoco a
monotonia e a humildade; e, depois, tudo é loucura (...) (POE,
2008, p. 111)

Fica evidente que o protagonista, enquanto estava praticamente desacordado, foi "transportado para outro espaço", pois foi erguido e arrastado por figuras que, na condição dele, pareciam ser apenas sombras. Depreendese a coordenada espacial relacionada à verticalidade e que se desdobra nos pólos alto $x$ baixo. $O$ personagem foi para um espaço cada vez mais baixo; 0 fato de descer remete às idéias de subterrâneo e de inferno. A simbologia do inferno é inclusive levantada pelo próprio protagonista quando cita a figura mitológica do Hades. E isso condiz com a temática do conto, já que a morte é algo negativo, ainda mais sentenciada. Não se sabe do passado do personagem, mas se foi condenado à morte, fez algo para receber tal sentença.

Passemos agora à análise do segundo espaço.

\section{Espaço da prisão}




\begin{tabular}{|l|l|l|l|l|l|l|}
\hline InterteXto & Uberaba & UFTM & $\begin{array}{l}\text { v. 2 } \\
\text { n. } 2\end{array}$ & p. 52-74 & 2009 - jul. / dez. & ISSN 1981-0601 \\
\hline
\end{tabular}

O personagem recupera sua consciência e, aos poucos, começa a se lembrar vagamente do que acontecera. A seguir, ele tenta perceber algumas características do novo espaço em que se encontrava.

Até aqui, não tinha aberto os olhos. Sentia que estava deitado de costas, desamarrado. Estiquei a mão, e ela caiu pesadamente sobre algo úmido e duro. Deixei que ela ali ficasse alguns minutos, enquanto me esforçava por descobrir onde poderia estar e o que eu poderia ser. Ansiava por servirme dos olhos, mas não ousava fazê-lo. Receava o primeiro olhar para os objetos que me cercavam. Não que eu temesse olhar para coisas horríveis, mas horrorizava-me o receio de que nada houvesse para ver. (POE, 2008, p. 112)

O protagonista, temeroso do que poderia ver, opta por perceber o espaço tateando. Tem-se, assim, a exploração do gradiente sensorial do tato, que é um tanto limitado se comparado à visão, à audição e ao olfato. Num local escuro, em que o sentido da visão fica comprometido, o tato é o sentido usado para se situar dentro do espaço. Vale ressaltar que esse sentido já sugere certo desconcerto, pois a noção de tatear sem ver sugere a condição de perdido e desnorteado do personagem. As únicas impressões percebidas são a de dureza e umidade. Nesse caso, a espacialização é dissimulada, ou seja, o espaço é introduzido na narrativa através da ação do personagem de tatear. Porém, ainda não se pode depreender mais características dele, devido ao caráter limitado do tato. No excerto seguinte, o narrador decide olhar o local em que se encontra:

Por fim, com fero desespero em meu coração, abri rapidamente os olhos. Meus piores pensamentos, então, confirmaram-se. O negror da noite eterna rodeava-me. Esforcei-me para respirar. A intensidade das trevas parecia oprimir-me e sufocar-me. A atmosfera estava intoleravelmente confinada. (POE, 2008, p. 112)

Ao abrir os olhos, o personagem percebe uma característica que já havia sido apontada no espaço em que se encontrava anteriormente: a escuridão. Mais uma vez, são sugeridas as idéias de angústia e de inferno, idéia esta que 


\begin{tabular}{|l|l|l|l|l|l|l|}
\hline InterteXto & Uberaba & UFTM & $\begin{array}{l}\text { v. 2 } \\
\text { n. 2 }\end{array}$ & p. 52-74 & 2009 - jul. / dez. & ISSN 1981-0601 \\
\hline
\end{tabular}

casa com a coordenada espacial do baixo (verticalidade). O ar pesado, capaz de sufocar, evidencia como o espaço é claustrofóbico e como, conseqüentemente, topofóbico, despertando sentimentos negativos.

Após essa primeira impressão visual de escuridão, o protagonista do conto começa a se perguntar sobre seu destino e, mais uma vez, aparecem referências ao espaço.

Tinha eu sido reenviado para meu calabouço, à espera do próximo sacrifício seguinte, que não seria realizado senão dali a muitos meses? Vi logo que não podia ser isso. As vítimas haviam sido requisitadas imediatamente. Além do mais, meu calabouço, assim como todas as celas de condenados em Toledo, tinha chão de pedra e não era inteiramente privado de luz. (POE, 2008, p. 112-113)

Calabouço pode ser definido como uma prisão subterrânea, um cárcere, cadeia. Se considerarmos a relação entre o nome do local e a situação em que está se desenrolando o enredo, podemos perceber uma relação toponímica. 0 local é chamado de calabouço para reforçar ou expor uma característica do espaço que condiz com o terror do momento. Além disso, por se utilizar da palavra calabouço, o narrador provoca um sentido de realidade $\mathrm{e}$ verossimilhança, ainda mais em tempos como aqueles. Assim, o espaço evidencia a posição do personagem, de estar preso, esperando pela morte que Ihe havia sido sentenciada. Aos poucos, se podem ter noções mais concretas do espaço; o chão era de pedra e, embora primeiramente o personagem tenha achado o lugar muito escuro, aos poucos foi se acostumando e conseguindo ver que a luz não estava totalmente ausente. Nessa parte a espacialização continua como reflexa, introduzida pelo personagem.

Posteriormente, o protagonista resolve se levantar e fazer um reconhecimento do lugar em que estava. Ele estende os braços, amedrontado, em busca de algum raio de luz. A incerteza fez com que ele agisse com cautela, e ele acabou por tatear a parede do calabouço, como se percebe no trecho seguinte: 


\begin{tabular}{|l|l|l|l|l|l|l|}
\hline InterteXto & Uberaba & UFTM & $\begin{array}{l}\text { v. 2 } \\
\text { n. } 2\end{array}$ & p. 52-74 & 2009 - jul. / dez. & ISSN 1981-0601 \\
\hline
\end{tabular}

Minhas mãos estendidas encontraram, afinal, um sólido obstáculo. Era uma parede, aparentemente de pedra, muito lisa, viscosa e fria. Fui acompanhando-a, caminhando com toda a cuidadosa desconfiança que certas narrativas antigas tinhamme inspirado. Esse processo, porém, não me proporcionava meios de verificar as dimensões do calabouço; pois eu podia fazer-lhe o percurso e voltar ao ponto de onde partira sem dar por isso, tão perfeitamente uniforme parecia a parede. Assim sendo, procurei a faca que havia estado em meu bolso quando me levaram à sala inquisitorial, mas ela não estava mais lá. (POE, 2008, p. 113-114)

É a ação do personagem, de estender as mãos e caminhar pelo local, que evidencia o espaço nessa passagem. Por isso, tem-se uma espacialização dissimulada. Devido à pouca luminosidade do local, o gradiente sensorial a ser explorado, mais uma vez, é o tato. A imprecisão que esse gradiente oferece é coerente com a perturbação e a incerteza do protagonista que, ao esperar pela morte, anseia em saber quando e como esse fato irá se suceder.

Algumas características podem ser depreendidas das paredes do local, que parecem ser de pedra, lisas e, como já foi citado anteriormente, mais uma vez aparece a sensação de umidade do local. A umidade sugere o caráter sórdido do calabouço, pouco ventilado, onde o sol não é capaz de atingir e aquecer. Juntamente com a escuridão, ela ajuda a compor um ambiente macabro, fechado, topofóbico, propiciando ações maléficas.

Agora, o personagem quer saber a extensão do local, deseja ter uma noção melhor de algumas coordenadas espaciais envolvidas. Por isso ele elabora um plano para perceber as dimensões, assim como se pode ver na passagem:

Rasguei uma parte do debrum da roupa e coloquei o fragmento bem estendido em um ângulo reto com a parede. Tateando meu caminho em torno da prisão, não poderia deixar de encontrar aquele trapo ao completar o circuito. Pelo menos, assim pensava eu, mas não contara com a extensão do calabouço, nem com minha fraqueza. O chão estava úmido e escorregadio. Cambaleante, caminhei para a frente durante algum tempo, mas tropecei e caí. Minha excessiva fadiga 


\begin{tabular}{|l|l|l|l|l|l|l|}
\hline InterteXto & Uberaba & UFTM & $\begin{array}{l}\text { v. 2 } \\
\text { n. } 2\end{array}$ & p. 52-74 & 2009 - jul. / dez. & ISSN 1981-0601 \\
\hline
\end{tabular}

induziu-me a permanecer deitado, e logo o sonho se apoderou de mim naquele estado. (POE, 2008, p. 114)

Assim, para ter maiores noções do espaço, o personagem usa de um pedaço de pano colocado perpendicularmente à parede. É perceptível como a dúvida e a indefinição do calabouço aumentam a agonia e a ansiedade do homem, que fica desesperado tentando descobrir como é aquela prisão. A umidade, mais uma vez presente, sugere uma certa frieza do lugar, oferecendo à narrativa um clima psicológico que, somado com a escuridão, fica ainda mais macabro. O novo desmaio do protagonista mostra como o lugar era desagradável e topofóbico. Há a presença de um ambiente amedrontador, indefinido, misterioso.

O prisioneiro então, com esperanças de explorar e de entender aquele espaço continua o circuito e constata o seguinte:

Havia, pois, ao todo, uns cem passos. E admitindo dois passos para cada metro, presumi que o calabouço tivesse uns cinqüenta metros de circuito. Encontrara, porém, muitos ângulos na parede e, desse modo, não me era possível formar idéia de qual fosse a forma do sepulcro, pois sepulcro não podia deixar eu de supor que fosse. (POE, 2008, p. 114)

Reparem que nesse momento o personagem opera uma metamorfose espacial: o local que ele descrevia como calabouço, passou a ser chamado de sepulcro. Nesse ponto percebemos sua fragilidade psicológica em relação ao local. O seu temor e sua insegurança levam a crer que aquele local era o seu fim, o local onde o sepultariam. Essa toponímia traz a idéia da morte mais uma vez, de um local totalmente inescapável.

Desse modo o protagonista resolve andar pelo espaço. Mesmo sem luz ele tinha esperanças de que pudesse escapar desse tormento. Contudo, havia dado poucos passos quando tropeça em seu debrum e cai de rosto ao chão. $E$ o que ele percebeu chamou sua atenção.

Estendi o braço e estremeci ao descobrir que havia caído mesmo à beira de um poço circular, cuja fundura, sem dúvida, 


\begin{tabular}{|l|l|l|l|l|l|l|}
\hline InterteXto & Uberaba & UFTM & $\begin{array}{l}\text { v. 2 } \\
\text { n. } 2\end{array}$ & p. 52-74 & 2009 - jul. / dez. & ISSN 1981-0601 \\
\hline
\end{tabular}

não tinha meios de avaliar no momento. Apalpando a parede logo abaixo da borda, consegui deslocar um pequeno fragmento e deixei-o cair dentro do abismo. Durante muitos segundos, prestei ouvidos a suas repercussões, ao bater de encontro aos lados da abertura durante a queda. Por fim, ouvi um lúgubre mergulho n'água, seguido de ruidosos ecos. (POE, 2008, p. 115)

Sem querer, o personagem descobre uma das armadilhas que os inquisidores tinham colocado ali de propósito. Agora percebemos que a privação de luz não era mera coincidência. A percepção do espaço acontece de maneira diferente, não pela visão: pelo tato e pela audição (o eco da pedra batendo nas paredes do poço). O poço é tido como uma figura complexa por sua percepção e, por isso, macabro. É visto como se estivesse longe (ele tenta ver o poço apesar da escuridão) e ao mesmo tempo está bastante próximo já que ele consegue tocar e ouvir. A noção de abismo sem fim vem novamente reforçar a idéia do indefinido, do espaço vago. Pesquisando no Dicionário de símbolos (2008, p.726), encontramos uma definição bastante interessante:

O poço se reveste de um caráter sagrado em todas as tradições: ele realiza uma espécie de síntese de três ordens cósmicas: céu, terra, infernos; de três elementos: a água, a terra e o ar; ele é uma via vital de comunicação. É também, ele próprio, um microcosmo, ou síntese cósmica. Ele faz a comunicação com a morada dos mortos; o eco cavernoso que sobe dele, os reflexos fugidios da água quando se agita, aumentam o mistério mais do que o esclarecem. Considerando de baixo para cima, é uma luneta astronômica gigante, apontada desde o fundo das entranhas da terra para o pólo celeste. Esse complexo constitui uma escada de salvação ligando entre si os três andares do mundo.

O poço, portanto, seria a comunicação, a "porta de entrada" para o inferno, para o mundo subterrâneo, ou seja, a morte, a decadência. Além disso, por ser circular, remete às simbologias da "ausência de distinção" e do "mundo espiritual". Novamente retoma as idéias de indefinido e de morte.

Essa era apenas uma das mortes perturbadoras que os inquisidores poderiam provocar no prisioneiro. A idéia de morte é ligada o tempo todo com 


\begin{tabular}{|l|l|l|l|l|l|l|}
\hline InterteXto & Uberaba & UFTM & $\begin{array}{l}\text { v. 2 } \\
\text { n. 2 }\end{array}$ & p. 52-74 & 2009 - jul. / dez. & ISSN 1981-0601 \\
\hline
\end{tabular}

as lembranças que o protagonista fazia das torturas provocadas pelos monges da época: "(...) era daquela mesma natureza que eu considerava fabulosa e absurda nas histórias a respeito da Inquisição." (p.115); "repulsivos emblemas a que a superstição sepulcral dos monges tem dado origem.” (p.117); “(..) vieram-me à memória mil vagos boatos a respeito dos horrores de Toledo." (p.113).

Esse era o movimento da tortura, peculiar e bastante comum na época da narração: a Inquisição. No seguinte trecho podemos deduzir a respeito dos indícios da época e do espaço:

\begin{abstract}
A sentença fora pronunciada; parecia-me que um longuíssimo intervalo de tempo havia, desde então, decorrido. Contudo, nem por um momento supus que estivesse realmente morto. Tal suposição, malgrado o que lemos em romances, é de todo incompatível com a existência real - mas, onde estava eu e em que estado me encontrava? Sabia que os condenados à morte pereciam comumente em autos-de-fé, e um deles ocorrera bem na noite do dia do meu julgamento. Tinha eu sido reenviado para meu calabouço à espera do próximo sacrifício, que não seria realizado senão dali a muitos meses? Vi logo que não podia ser isso. As vítimas haviam sido requisitadas imediatamente. Além do mais, meu calabouço, assim como todas as celas de condenados em Toledo, tinha chão de pedra e não era inteiramente privado de luz. (POE, 2008, p. 113)
\end{abstract}

A época em que se passa a história é o da Inquisição. Qualquer pessoa que fosse considerada perigosa à sociedade ou que realizava alguma atitude subversiva era logo condenada e atirada à fogueira ou à tortura, isso depois de passar pelos chamados autos-de-fé ${ }^{4}$. Ainda mais um homem como o protagonista, que admite ser um rebelde. E toda essa tortura física e psicológica provavelmente já se passara há algum tempo na vida do personagem devido a verbos que ele emprega no pretérito, como o mais-queperfeito: ocorrera.

\footnotetext{
${ }^{4}$ Autos-de-fé eram cerimônias que acompanhavam a pronunciação da sentença do Santo Ofício e a seguinte execução destas pelas autoridades seculares, quase sempre mediante a purificação pelo fogo.
} 


\begin{tabular}{|l|l|l|l|l|l|l|}
\hline InterteXto & Uberaba & UFTM & $\begin{array}{l}\text { v. 2 } \\
\text { n. 2 }\end{array}$ & p. 52-74 & 2009 - jul. / dez. & ISSN 1981-0601 \\
\hline
\end{tabular}

O espaço também pode ser especulado. A cidade a que ele se refere é, muito provavelmente, a cidade espanhola de Toledo. A Espanha foi considerada um dos países em que o Santo Ofício foi mais rigoroso e cruel. Por ser um espaço real, que existe em nosso mundo físico, BARTHES (1972, p. 35 e ss.) chama de "efeito de real", ou seja, o local traz um efeito de verdade para o conto.

Outro item a ser analisado aqui é o tempo. Todo o conto é caracterizado pelo tempo cronológico, ou seja, as ações acontecem ao longo de uma estrutura de tempo linear. Porém, observamos algumas passagens em que o protagonista sofre com o seu próprio tempo psicológico, que é quando ocorrem os desmaios, e ele se encontra em sua própria dimensão de sonhos e delírios. Nesses momentos ele não reconhece a passagem do tempo: "parecia-me que um longuíssimo intervalo de tempo havia, desde então, decorrido". É nesses momentos de desmaio que notamos a presença até mesmo de fluxos de consciência, que podem ser justificados pelo seu estado de decadência física e psicológica.

Encontramos ainda a presença da metanarrativa. Ele comenta sobre sua própria escrita e sobre a literatura: "tal suposição, malgrado o que lemos em romances" (p.113); "Pareciam-me brancos, mais brancos do que a folha de papel sobre a qual traço estas palavras (...)". (p.109).

Após perceber que escapou da morte por um triz, o prisioneiro bebe de uma bilha d'água e cai em outro desmaio. Quando acorda ele nota que havia agora uma luz mais viva e sulfúrea, a ponto de ele poder enxergar e discernir o espaço no qual se encerrava. A presença agora de pouca luz pode indicar que o seu tormento poderia estar chegando ao fim, apesar de sua situação ter mudado de figura. Veja: 


\begin{tabular}{|l|l|l|l|l|l|l|}
\hline InterteXto & Uberaba & UFTM & $\begin{array}{l}\text { v. 2 } \\
\text { n. } 2\end{array}$ & p. 52-74 & 2009 - jul. / dez. & ISSN 1981-0601 \\
\hline
\end{tabular}

Graças a uma luz viva e sulfúrea, cuja origem não pude a princípio determinar, estava capacitado a ver a extensão e o aspecto da prisão.

Havia-me enganado, e muito, quanto ao seu tamanho. $O$ circuito completo de suas paredes não excedia vinte e cinco metros. Por alguns minutos, esse fato originou em meu espírito um mundo de inútil perturbação; inútil, de fato, pois que coisas havia de menor importância nas terríveis circunstâncias que me cercavam que as simples dimensões de meu calabouço? (...) Ao tatear meu caminho, descobrira muitos ângulos e daí deduzi a idéia de grande irregularidade, tão poderoso é o efeito da escuridão absoluta sobre alguém que desperta do letargo ou do sono. Os ângulos eram apenas os de umas poucas e ligeiras depressões, ou nichos, a intervalos desiguais. Era quadrada a forma geral da prisão. O que eu tinha tomado por alvenaria parecia, agora, ser de ferro ou qualquer outro metal, em enormes chapas, cujas suturas ou juntas ocasionavam aquelas depressões. Toda a superfície desse recinto metálico estava grosseiramente pintada com horríveis e repulsivos emblemas a que a superstição sepulcral dos monges tem dado origem. Figuras de demônios em atitudes ameaçadoras, com formas de esqueletos, e outras imagens mais realisticamente apavorantes se espalhavam por todas as paredes, desfigurando-as. Observei que os contornos daquelas monstruosidades eram bem distintos, mas que as cores pareciam apagadas e borradas, como se por efeito da atmosfera úmida. Notei, também, que o chão era de pedra. No centro, escancarava o poço circular, de cujas fauces havia eu escapado, mas era o único que existia no calabouço.

Vi tudo isso indistintamente e com bastante esforço, pois minha situação tinha sofrido grande alteração durante o sono. Encontrava-me agora deitado de costas e bem esticado, numa espécie de armação de madeira de pouca altura. Estava firmemente amarrado a ela por uma comprida correia, semelhante a um loro. (POE, 2008, p. 116-117)

O mais notável é que mesmo com a luz que agora se fazia presente no recinto, a sensação de deformidade e irregularidade ainda era constante: havia ângulos, a escuridão deformara a idéia do prisioneiro sobre a prisão, as figuras modificavam as paredes, a sua pintura estava apagada. O que vem ao encontro de um sentimento de desespero já comentado anteriormente. Apesar disso, nota-se a grande preocupação do protagonista em descobrir o espaço 


\begin{tabular}{|l|l|l|l|l|l|l|}
\hline InterteXto & Uberaba & UFTM & $\begin{array}{l}\text { v. 2 } \\
\text { n. } 2\end{array}$ & p. 52-74 & 2009 - jul. / dez. & ISSN 1981-0601 \\
\hline
\end{tabular}

no qual estava encerrado. Mesmo tendo a aparência de um calabouço, o protagonista precisa saber realmente como é esse espaço para ter uma sensação de equilíbrio psicológico, como se lutasse contra o espaço.

Agora voltemos a atenção para as dimensões. O homem, devido à escuridão, tivera a impressão de que o poço fosse circular; porém a luminosidade também trouxe o esclarecimento. A forma geral da prisão era quadrada, cheia de irregularidades. A simbologia do quadrado remete à terra, em contraposição ao céu, à antítese ao transcendente, à estagnação, à solidificação. E é justamente essa estagnação, essa impossibilidade de sair daquele local que o quadrado vem representar.

Notamos ainda que as paredes da prisão não eram feitas de alvenaria, como se supunha, mas sim de algum metal, como o ferro. O metal simboliza a solidificação, enquanto que o ferro simboliza a dureza, a robustez. Esses elementos simbólicos combinam ao elemento do quadrado. Tudo indica que aquele local é impenetrável, definitivamente fechado, recluso, impossibilitando qualquer maneira de escapatória. Por esses mesmos motivos é que no conto não há presença da paisagem (não há uma extensão espacial capaz de ser observada e muito menos a presença da fruição), já que o local nem mesmo pode ser explorado em sua integridade.

Pela primeira vez, o protagonista enxerga as bizarras figuras que "ornam" as paredes de ferro. Elas também não estão ali por mero acaso. Como ele mesmo notou, as figuras eram uma arte macabra, uma forma de intimidação, por se utilizarem de motivos fúnebres: imagens de esqueletos, de demônios.

Nesse trecho a situação em que se encontra a personagem muda drasticamente. Os torturadores o prenderam firmemente em uma espécie de armação de madeira, como uma cama. E dessa cama seus movimentos são limitados assim como seu campo visual. O espaço nesse caso se tornou ainda mais limitado, assim como o seu poder sobre ele. Nesse ponto somos capazes de afirmar que o espaço do calabouço exerce majoritariamente duas funções: influenciar a personagem e propiciar a ação. 


\begin{tabular}{|l|l|l|l|l|l|l|}
\hline InterteXto & Uberaba & UFTM & $\begin{array}{l}\text { v. 2 } \\
\text { n. } 2\end{array}$ & p. 52-74 & 2009 - jul. / dez. & ISSN 1981-0601 \\
\hline
\end{tabular}

Como já foi discutido, o espaço é fechado e claustrofóbico. E isso não é fortuito. Pela época da Inquisição, tudo isso era muito justificável para incitar o medo e o pânico nos condenados. Além disso, o autor não poderia transmitir essa idéia de desespero e angústia se não fosse num local estranho como esse. E, obviamente, é o espaço e no espaço que se propicia a ação. Quase toda a trama se passa como uma tentativa de forças opostas: o prisioneiro tentando uma maneira de escapar do local enquanto o espaço (e as pessoas que comandam o espaço) tentam aniquilar o homem da maneira mais fria e cruel possível. $E$ os monges e inquisidores eram senhores absolutos do espaço, assim como o prisioneiro era subserviente a ele. Os inquisidores sabiam exatamente até mesmo quando ele desmaiava ou quando ele escapava de uma e de outra armadilha.

Momentos depois, o teto do calabouço chama a atenção do protagonista.

Olhando para cima, examinei o teto da minha prisão. Tinha uns dez ou doze metros de altura e era construído de maneira idêntica à das paredes laterais. Em um de seus painéis, uma figura bastante singular absorveu-me toda a atenção. Era a pintura do Tempo, tal como é comumente representado, salvo por, em lugar da foice, segurar ele aquilo que, a uma olhada casual, supus ser o desenho de um enorme pêndulo, como o que vemos nos relógios antigos. (POE, 2008, p. 118)

Esse é o momento da descoberta da nova tentativa de tortura imposta ao prisioneiro: o pêndulo. $E$ este pêndulo foi comparado a uma imagem bastante representativa: o Tempo. O Tempo neste caso também pode representar a Morte. O pêndulo, como ele pôde observar mais adiante não era somente uma marcação de um relógio antigo. Era "metaforicamente" a marcação do tempo para a sua morte. Esta maquinaria foi construída para abaixar e rasgar sua carne até o ponto de matá-lo, de uma maneira lenta e dolorosa. O que é bastante notável nesse tormento é o gradiente sensorial da audição: "o conjunto assoviava ao balançar-se no ar". Era o único som capaz de se ouvir no recinto. $O$ que associa também o assovio do pêndulo com o barulho do pêndulo do relógio: a contagem regressiva para o momento final. 


\begin{tabular}{|l|l|l|l|l|l|l|}
\hline InterteXto & Uberaba & UFTM & $\begin{array}{l}\text { v. 2 } \\
\text { n. } 2\end{array}$ & p. 52-74 & 2009 - jul. / dez. & ISSN 1981-0601 \\
\hline
\end{tabular}

De acordo com o Dicionário de Símbolos (2008, p.876) o tempo é uma característica indissociável ao espaço. Para Santo Agostinho o tempo é "a imagem móvel da imóvel eternidade". E também se relaciona à morte. Para Baudelaire o tempo é "o inimigo vigilante e funesto"; para lendas celtas o tempo é o sinônimo de morte.

Portanto outros aspectos dos gradientes sensoriais podem ser aqui analisados. Observem:

Dias se passaram - pode ser que se tenham passado muitos dias - até que ela se balançasse tão perto de mim que me abanava com seu sopro ácrido. O odor da lâmina afiada entrava-me pelas narinas. (POE, 2008, p.119)

De acordo com Borges Filho (2007, p.69), "efeitos de sentido importantes são manifestados nessa relação sensorialidade-espaço", de acordo com a distância/proximidade entre os gradientes e o espaço. Desse modo, analisemos a relação da distância entre o pêndulo e o prisioneiro. Reparemos que a percepção do homem através de seus sentidos se intensifica cada vez mais: primeiramente ele vê a cimitarra, depois ele ouve o seu assovio e por fim, quando ela está quase o alcançando, ele sente o seu cheiro. A essa relação visão, audição, olfato que é mostrado em Espaço e literatura: introdução à Topoanálise, podemos associar a proximidade da morte, ao tempo que está marcado para a execução final. Assim, podemos também fazer outra analogia interessante. Tomando o sentido das coordenadas espaciais alto/ baixo (verticalidade) podemos fazer o seguinte esquema:

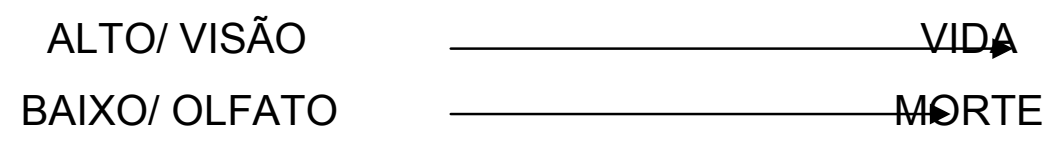

Então voltemos novamente a esse tema constante da história: a morte. Ao longo de todo o conto, se atentarmos aos detalhes, percebemos que quando $o$ 


\begin{tabular}{|l|l|l|l|l|l|l|}
\hline InterteXto & Uberaba & UFTM & $\begin{array}{l}\text { v. 2 } \\
\text { n. } 2\end{array}$ & p. 52-74 & 2009 - jul. / dez. & ISSN 1981-0601 \\
\hline
\end{tabular}

protagonista olha para o alto, ou olha as paredes circundantes são os momentos em que ele tenta uma saída, uma escapatória, é quando uma mínima fonte de esperança parece iluminar a sua mente. Porém tudo que está relacionado à coordenada baixo, ao chão, é negativo, ligado à morte ou à tortura. É no poço profundo que se encontrava sua primeira armadilha, é para baixo que se dirige o objetivo mortal do pêndulo, é no chão ou perto do chão que se encontram os cheiros mais desagradáveis como o cheiro ácrido da lâmina, o cheiro de fungos podres do poço ou até mesmo o cheiro dos ratos.

Nesse trecho, outra sensação de tempo psicológico pode ser notada. $O$ medo da lâmina, ou a iminência da morte ocorre quando o protagonista entra num estado de delírio, de frenesi em que ele anseia pela morte e o tempo parece contar como dias.

Naquele local, os ratos fervilhavam e foi exatamente daí que surgiu a sua esperança. O personagem besuntou as correias com a gordura dos restos da comida e, desse modo, fez com que os ratos as roessem até que ele conseguisse escapar. E escapar da morte pela segunda vez. De acordo com CHEVALIER e GHEERBRANT (2008, p. 770) os ratos são caracterizados como criaturas terríveis, e até infernais. Podem-se utilizar os ratos para alguma vingança, assim como para alguma benfeitoria. Foi de onde ele menos esperava que surgiu a oportunidade.

E repentinamente, o terceiro e último tormento se faz presente. $O$ condenado percebe que toda a prisão estava ficando iluminada. Os inquisidores estavam ateando fogo à prisão do lado de fora e desse modo causando um calor infernal. Veja: 


\begin{tabular}{|l|l|l|l|l|l|l|}
\hline InterteXto & Uberaba & UFTM & $\begin{array}{l}\text { v. 2 } \\
\text { n. } 2\end{array}$ & p. 52-74 & 2009 - jul. / dez. & ISSN 1981-0601 \\
\hline
\end{tabular}

Até ao respirar vinha-me às narinas o bafo do vapor de ferro aquecido! Um odor sufocante derramava-se pela prisão! Um brilho mais profundo se fixava a cada momento nos olhos que contemplavam minhas agonias! Uma coloração carmesim mais rica difundia-se sobre as horrendas pinturas de sangue! (POE, 2008, p. 124)

Essa é a idéia de morte inescapável que o narrador criou nessa cena. Os olhos dos demônios pintados nas paredes se tornavam cada vez mais nítidos, o calor estava se tornando penetrante e incontrolável. Mais uma vez a sensação de odor (odor sufocante) torna-se presente já que com a relação de proximidade-olfato também se depreende uma relação mortal.

Outro elemento bastante importante de se notar aqui é o fogo. Na Inquisição, a morte mais recorrente era a queima na fogueira, pois se acreditavam que o fogo é o elemento da purificação espiritual. E associado ao fogo vem o símbolo do vermelho, do carmesim. Segundo o Dicionário de símbolos (2008 p.944) o vermelho, ao mesmo tempo que simboliza o princípio da vida e da força, se ele for espalhado, significa a morte. Portanto, o vermelho espalhado ao redor do homem é uma sentença de morte, uma espécie de sepultura. O interessante é que o momento em que o vermelho sobressai é o momento do clímax do conto, a decisão final.

Percebemos ainda que o espaço se fecha ainda mais em torno do condenado. A claustrofobia aumenta à medida que o homem se vê cercado pela morte. Veja: 


\begin{tabular}{|l|l|l|l|l|l|l|}
\hline InterteXto & Uberaba & UFTM & $\begin{array}{l}\text { v. 2 } \\
\text { n. } 2\end{array}$ & p. 52-74 & 2009 - jul. / dez. & ISSN 1981-0601 \\
\hline
\end{tabular}

Segunda alteração tinha se verificado na cela, e agora a mudança era evidentemente na forma. Como antes, foi em vão que tentei, a princípio, perceber ou compreender o que estava ocorrendo. Mas não me foi dado permanecer em dúvida por muito tempo. A vingança inquisitorial fora apressada por minha dupla fuga, e não havia mais possibilidade de negacear o Rei dos Terrores. O quarto fora quadrado. Notei que dois de seus ângulos de ferro eram agora agudos $e$ dois, consequentemente, obtusos. A terrível diferença aumentava velozmente, com ruído lamentoso e surdo. Em um instante, o aposento trocara sua forma pela de um losango. (POE, 2008, p. 124-125)

O próprio espaço se alterara. Aquilo que era quadrado e digno de robustez, agora era um losango, símbolo da porta dos mundos subterrâneos, assim como o poço, que fora o único lugar que sobrara do espaço inicial.

Porém o desfecho é relacionado à vida. O prisioneiro conseguiu escapar do local fechado.

Houve um ruído discordante de vozes humanas! Depois, um estrondoso toque, como o de muitas trombetas! $\mathrm{E}$ um rugido áspero, como o de mil trovões! Precipitadamente, recuaram as paredes abrasadas. Um braço estendido agarrou $\mathrm{o}$ meu quando, desfalecido, eu caía no abismo. Era o do general Lasalle. O exército francês entrara em Toledo. A Inquisição caíra nas mãos dos inimigos. (POE, 2008, p. 125)

Aqui percebemos mais claramente a época em que se passa a história: muito provável no século XVIII, época em que a Revolução Francesa estava explodindo, e que ainda havia cerimônias e torturas de Inquisição. No começo do conto, há uma epígrafe de uma quadra composta para o Clube dos Jacobinos. ${ }^{5}$

Outro fato que nos traz um efeito de real é a citação do General Lasalle. Este foi um general francês da época das guerras napoleônicas, premiado

\footnotetext{
${ }^{5}$ A turbulência social da França no fim do século XVIII levou às disputas de poder por parte da burguesia e a conseqüente eclosão da Revolução Francesa. $\mathrm{E}$ com ela houve também o surgimento de novas forças políticas, como os jacobinos. Eles desejavam o triunfo da revolução, através do extremismo e, por isso, criaram um centro de atividades políticas: o Clube dos Jacobinos.
} 


\begin{tabular}{|l|l|l|l|l|l|l|}
\hline InterteXto & Uberaba & UFTM & $\begin{array}{l}\text { v. 2 } \\
\text { n. 2 }\end{array}$ & p. 52-74 & 2009 - jul. / dez. & ISSN 1981-0601 \\
\hline
\end{tabular}

como o melhor comandante de tropas de todos os tempos. Evocava entre os combatentes confiança, bravura e autoridade. Logo, a tropa que invadiu a prisão era a melhor comandada da época; Lasalle viveu entre 1775 e 1809, o que atribui uma temporalidade específica ao conto: século XVIII.

Dessa maneira, outro conceito que podemos explorar dentro da Topoanálise é a noção de território. De acordo com BORGES FILHO (2007, p. 28, 30):

Território é o espaço dominado por algum tipo de poder, é o espaço enfocado do ponto de vista político ou da relação de dominação-apropriação.

O poder, isto é, a vontade de um sobre o outro pode ser exercida de duas formas basicamente: pela coerção ou pela sedução.

A coerção acontece quando se usa a penalidade, a punição, seja ela qual for, para que a vontade de alguém seja colocada em prática.

A sedução é uma maneira sutil de levar alguém a agir de tal maneira (...).

Então, através dos dados acima, afirmamos que em todo o conto houve relações de territorialidade. A guerra que podemos notar no desfecho, no qual o exército francês invade a Espanha e impõe suas vontades à força, é uma maneira que o espaço foi disputado por coerção (quando punições, penalidades e rebeliões acontecem para que a vontade de alguém seja posta em prática num espaço).

\section{Conclusão}

O conto $O$ poço e o pêndulo é inteiramente construído através das relações do personagem com o espaço. O percurso espacial do conto é construído por dois espaços: o local onde o protagonista primeiramente recebe a sentença e o local para onde é levado e assim permanece preso.

Além do espaço, vê-se como o contexto histórico se apresenta de forma sutil e merece um destaque especial. O leitor pouco observador e que não sabe discernir os movimentos históricos terá dificuldade em compreender 


\begin{tabular}{|l|l|l|l|l|l|l|}
\hline InterteXto & Uberaba & UFTM & $\begin{array}{l}\text { v. 2 } \\
\text { n. } 2\end{array}$ & p. 52-74 & 2009 - jul. / dez. & ISSN 1981-0601 \\
\hline
\end{tabular}

elementos citados pelo narrador, como a cidade de Toledo, o general Lasalle, a época da Inquisição, da revolução, etc. Assim, é visível o engenho no trato das referências histórias, que não se encontram explicitadas, mas sim sutilmente concatenadas com o enredo do conto.

O cenário aparece de uma forma macabra e os elementos que explicitam esse caráter amedrontador aparecem ao longo de toda a narrativa. Assim, a topofobia é bastante presente e é coerente com a situação em que o personagem se encontra: a prisão, a certeza da morte e a incerteza de como e quando ela ocorrerá. A topofobia se dá mais precisamente através da claustrofobia; um local fechado, sem ventilação, cheio de umidade, ratos, frieza, propiciando a formação de um ambiente de angústias, incertezas, desespero, dúvidas. Isso evidencia o sentimento vivido pelo personagem.

Além da noção da interioridade, bastante explorada na diegese, um par de coordenadas decisivo para o conto é o alto/baixo. O movimento do pêndulo, descendente, explicita que a morte é iminente, e é exatamente a progressividade desse movimento que faz com que o protagonista pense numa maneira de escapar do seu fado de morte. Desse modo, é visível como o espaço propicia a ação e influencia o homem a lutar pela vida. Logo no início, já há a antecipação de que o personagem escapará da morte porque é ele próprio quem narra sua experiência; porém, a expectativa pelo clímax e desfecho é permanente durante toda a leitura do conto.

Os gradientes sensoriais são importantes elementos, pois a visão, a audição, o olfato e o tato, de forma particular, contribuem para que o ambiente macabro e de morte sejam formados. O protagonista, com sua visão limitada pela ausência de luz, precisa se contentar com as percepções obtidas pelo tato, pelo cheiro e pelos ruídos. Isso aumenta a incerteza que ele tem quanto ao local em que está e quando irá morrer e de que maneira.

Assim, em $O$ poço e o pêndulo, há uma relação toponímica de semelhança; o espaço é construído analogamente à temática da narrativa, sugerindo um local propício para se esperar pela morte e também coerente 


\begin{tabular}{|l|l|l|l|l|l|l|}
\hline InterteXto & Uberaba & UFTM & $\begin{array}{l}\text { v. 2 } \\
\text { n. 2 }\end{array}$ & p. 52-74 & 2009 - jul. / dez. & ISSN 1981-0601 \\
\hline
\end{tabular}

com a confusão psicológica vivida pelo personagem. Porém, apesar de previsto por elementos da narrativa, o final é inesperado; o conto explora a condição humana diante de situações extremas e a capacidade de, com persistência e engenho, escapar delas. Vê-se a metáfora do homem do século XVIII: é preciso agir de modo a não sucumbir às formas de coerção e de poder.

\section{Referências}

BARTHES, Roland. O efeito do real In Literatura e Semiologia. Petrópolis: Vozes, 1972.

BORGES FILHO, Ozíris. Espaço e Literatura: Introdução à Topoanálise. Franca: Ribeirão Gráfica e Editora, 2007.

CHEVALIER, Jean \& GHEERBRANT, Alain. Dicionário de Símbolos. Rio de Janeiro: José Olympio, 2008.

Nova Enciclopédia Barsa. São Paulo: Barsa Consultoria Editorial Ltda., 2001.

GENETTE, Gerard. O discurso da narrativa. Lisboa: Vega, 1977.

POE, Edgar Allan. Histórias extraordinárias. São Paulo: Companhia das Letras, 2008.

<http://www.poebrasil.com.br/>. Acesso em: 18/11/2009 